\title{
A Freeze-Fracture Study on the Basolateral Plasma Membrane of the Gastric Parietal Cells in Fasting and Refed Rats
}

\author{
Kazuo TAIRA, Kikuo Yasuno* and Susumu SHIBASAKI \\ Department of Anatomy (Prof. S. Shibasaki), Gunma University School of Medicine, Maebashi, Japan
}

Received March 12, 1984

\begin{abstract}
Summary. The basolateral plasma membrane of the gastric parietal cells in rats after fooddeprivation and food-restitution was studied by thin-section and freeze-fracture electron microscopy. A decrease in the number of tubulovesicles and dilatation of the canalicular lumen were generally observed in the parietal cells of the refed rats. Basal folds, demonstrated both in fasting and food-resupplied rat groups parietal cells by thin-section electron microscopy, appears as branched furrows on the $P$ face and branched wrinkles on the $E$ face plasma membrane by the freeze-fracture replica method. Parietal cells providing numerous basal folds appeared to be more numerous in refed rat gastric gland. The basal folds may represent, at least to some extent, a reservoir of a surplus plasma membrane and play an important role in secreting substances into and also absorbing substances from the blood capillary via the underlying connective tissue.
\end{abstract}

The gastric parietal cell has been characterized by its unique capacity to secrete gastric acid and by the presence of a large number of tubulovesicles in the cytoplasm and microvilli in the intracellular canaliculi (Kurosumi et al., 1958; ShIBASAKI, 1961; Leeson, 1973; Ito and Schofield, 1974; Berglindh et al., 1976; Osawa and Ogata, 1978). Parietal cells undergo marked morphological changes according to different functional activities. The active state, when stimulated to secrete gastric acid, is characterized by the dilatation of the canalicular lumen and a marked decrease in the number of tubulovesicles. The dilatation of the canalicular lumen in the active parietal cell has been explained by the membrane-conversion hypothesis: successive membraneconversion from tubulovesicle to luminal plasma membrane.

In contrast to the luminal plasma membrane, little attention has been paid to the basolateral surface of the parietal cells, and only a few reports have referred to this aspect of the cells (Berglindh et al., 1976; Borde and Perrelet, 1978; Schofield, Ito and Bolender, 1979; Sato, Spicer and Tashian, 1980; Helander, 1981). In the present study, we focused on the basolateral plasma membrane of gastric parietal cells with special attention to the basal folds in food-deprived and food-resupplied rats by thinsection electron microscopy and the freeze-fracture replica method.

\footnotetext{
* Present address of K. YAsuno: Department of Anatomy, Saitama Medical School, Moroyama-machi, Saitama, 350-04 Japan
} 


\section{MATERIALS AND METHODS}

Twenty adult male rats (Holzmann strain), weighing about 150 to $300 \mathrm{~g}$, were used in the present study. The animals, fed laboratory feed and given water ad libitum, were killed after two days fasting (fasting rats) or 30 min after feeding following two days fasting (refed rats) by decapitation. The stomach was cut into small pieces and immersed in $2.5 \%$ glutaraldehyde and $2 \%$ paraformaldehyde in $0.12 \mathrm{M}$ cacodylate buffer. Small tissue blocks were fixed for about $3 \mathrm{hrs}$ at about $4^{\circ} \mathrm{C}$. After washing with $0.12 \mathrm{M}$ cacodylate buffer containing $7.5 \%$ sucrose, small tissue blocks were prepared for thinsection and freeze-fracture electron microscopy.

\section{Thin-section electron microscopy}

Small tissue blocks were postfixed in $1 \%$ osmium tetroxide containing $0.5 \%$ glucose for $3 \mathrm{hrs}$ at $4^{\circ} \mathrm{C}$. They were subsequently dehydrated with an increasing series of ethanol, embedded in Epoxy resin and sectioned with diamond knives. Ultrathin sections were stained with uranyl acetate and lead acetate.

\section{Freeze-fracture electron microscopy}

After washing with a buffer solution, small tissue blocks were infiltrated with $30 \%$ glycerol dissolved in the same buffer solution for about $12 \mathrm{hrs}$, and subsequently set on a copper plate. The copper plate and the small tissue blocks were frozen on a brassblock type apparatus (Hitachi HFZ-1) cooled in liquid nitrogen. The frozen tissue blocks were fractured in the brass-block type apparatus equipped with a vacuum evaporator (Hitachi HU-5) at about $-110^{\circ} \mathrm{C}$ with a pressure of about $1 \times 10^{-6}$ Torr, then shadowed with platinum carbon and backed with carbon. To remove the organic materials, the replicas were immersed in a household bleach and washed in distilled water and mounted on copper grids.

Thin sections and freeze-fractured replicas were examined with JEM-100C and JEM-200CX type electron microscopes.

\section{RESULTS}

\section{Thin-section electron microscopy}

The rat gastric glands were composed of parietal, chief, neck mucous and endocrine cells. Parietal cells were usually pyramidal and scattered among the neighboring gastric cells. Parietal cells were characterized by the presence of closely packed tubulovesicles and well-defined intracellular canaliculi (Fig. 1). The cytoplasm contained a round or oval nucleus, a large number of prominent mitochondria, dense bodies and bundles of microfilaments. Well-developed tubulovesicles were characteristic in fasting rat parietal cells. In refed rat gastric glands, active parietal cells increased in number. Active parietal cells appeared to be smaller than the resting ones and contained a few tubulovesicles, closely packed mitochondria and an increased number of microvilli in the dilated intracellular canaliculi. However, the number of tubulovesicles and the canalicular microvilli appeared to vary among parietal cells at different locations in the gastric glands.

The lateral cell surfaces adjacent to the neighboring cells were equipped with tight junctions and interdigitations. There were basal folds, small projections and 
infoldings of the plasma membrane in the basolateral cell surface. The folds did not occur uniformly, but often at some intervals. The folds appeared to vary in number among parietal cells. However, they tended to be more numerous in refed rat parietal cells than in the fasting rat. Parietal cells containing a decreased number of tubulovesicles appeared to correspond to the cells providing more numerous basal folds.

\section{Freeze-fracture electron microscopy}

In freeze-fracture replicas, parietal cells were distinguished from other gastric cells by the presence of characteristic tubulovesicles, intracellular canaliculi and numerous mitochondria (Fig. 3). Bundles of microfilaments could be identified along the luminal as well as basal cell surfaces. Tubulovesicles appeared as abundant convex or concave

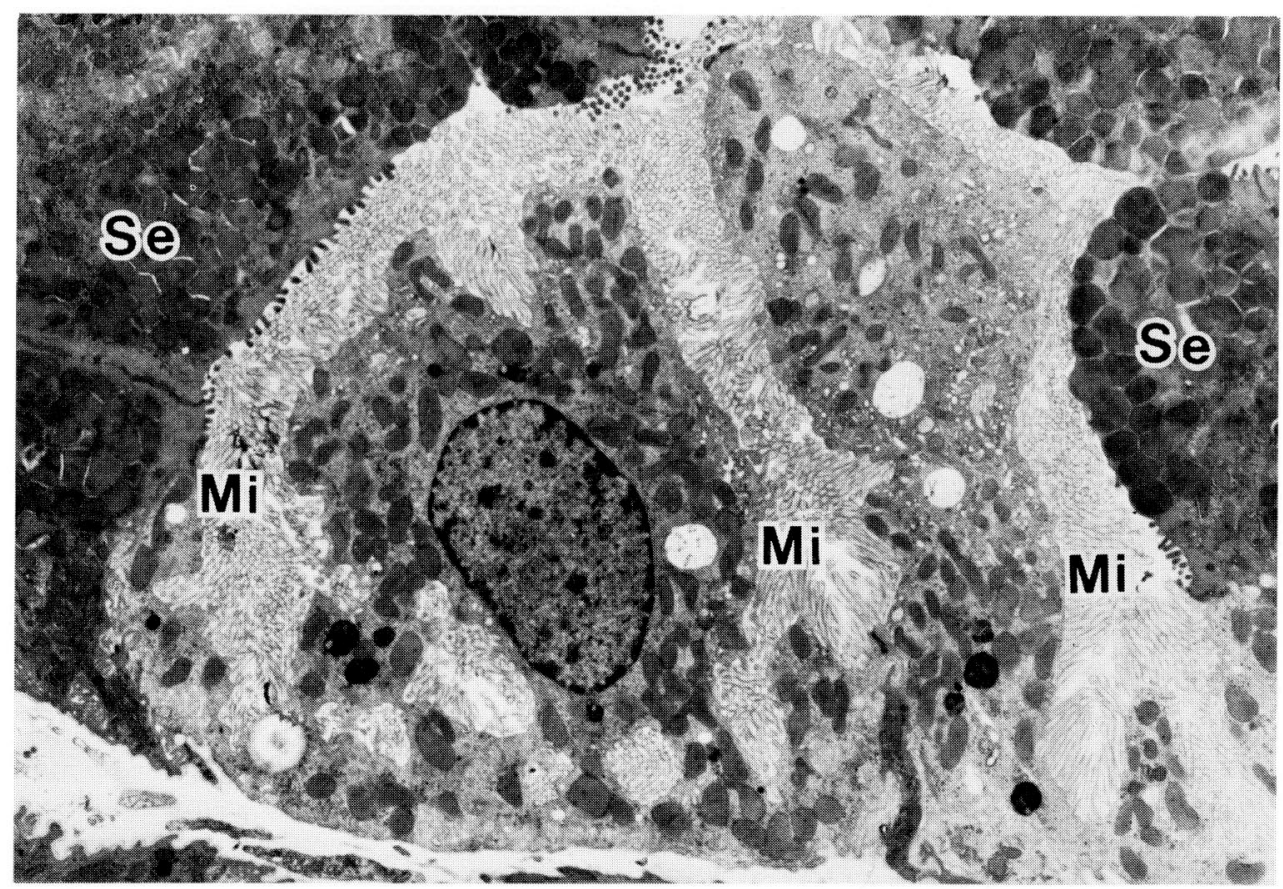

Fig. 1. Thin-section electron micrograph of a parietal cell in a refed rat. A dilated intracellular canalicular lumen is filled with microvilli $(M i)$. Se surface epithelial cell. $\times 4,100$

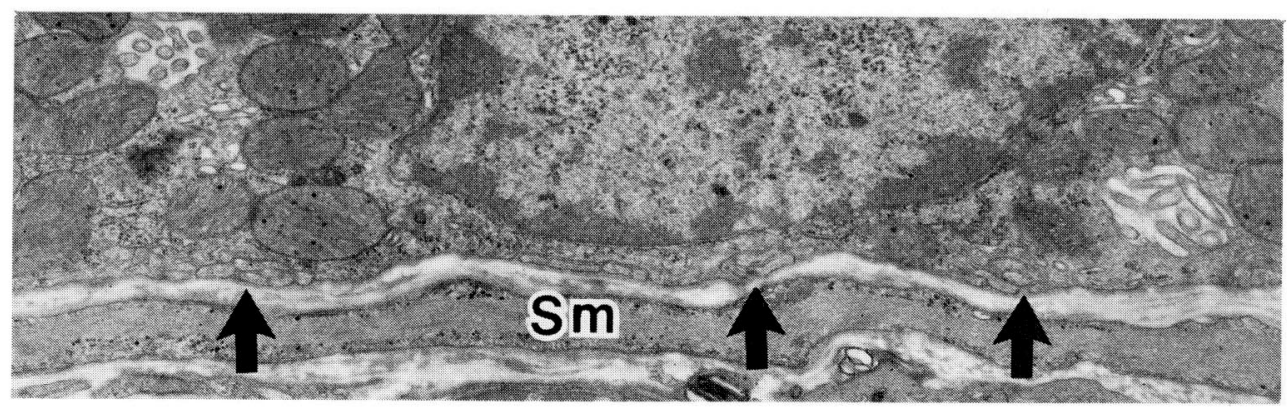

Fig. 2. Basal part of a parietal cell in a fasting rat. Irregularly shaped basal folds can be seen (arrows). A thin connective tissue layer is located between the parietal cell and smooth muscle cell $(\mathrm{Sm}) . \quad \times 12,000$ 


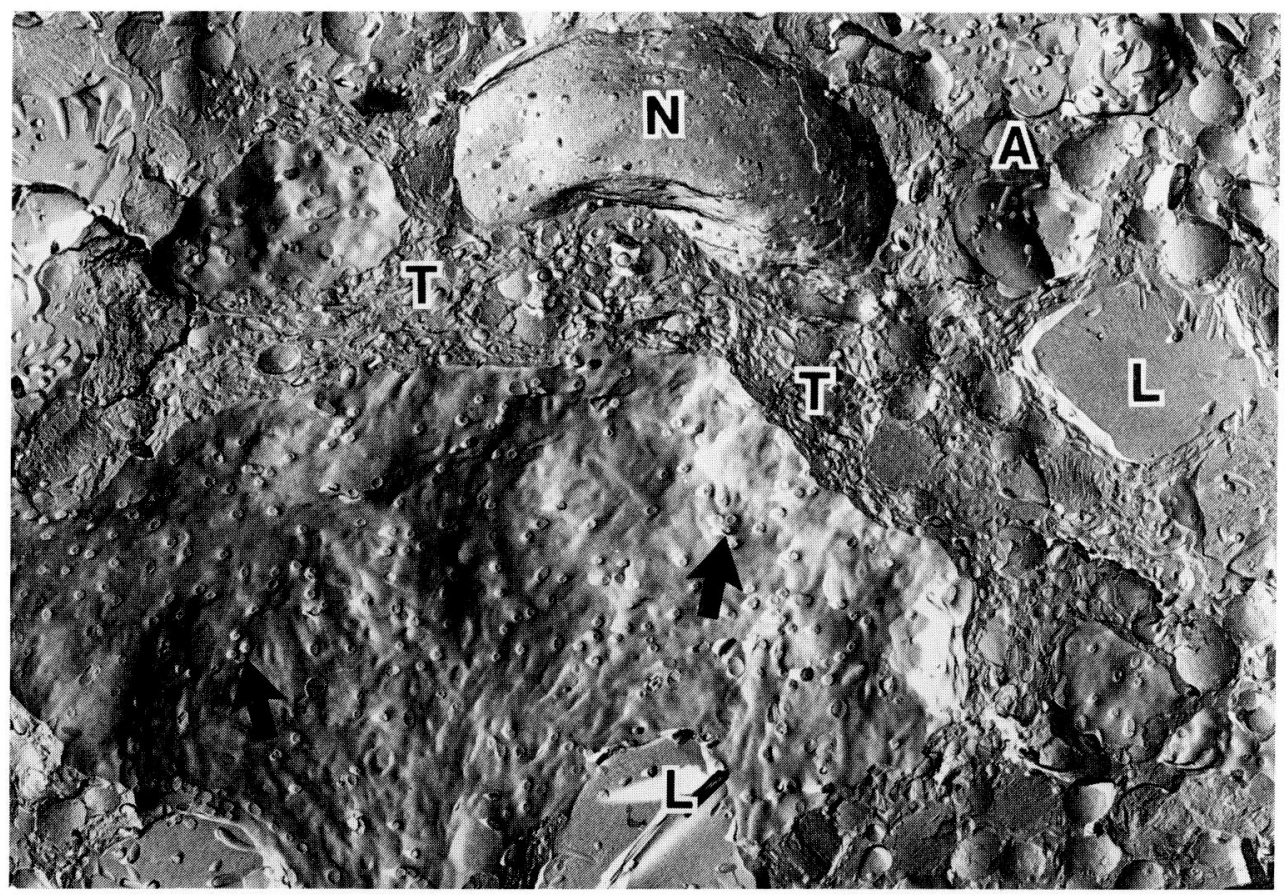

Fig. 3. Freeze-fracture replica of a parietal cell in a fasting rat. Numerous tubulovesicles $(T)$ and mitochondria are seen in the cytoplasmic area. Cross-fractured microvilli (arrows) stud the P plasma membrane face of the luminal surface. $L$ lumen, $N$ nucleus. $\quad \times 7,900$

corpuscles in the cytoplasm. Abundant intramembranous particles were seen on the $\mathrm{P}$ face of the tubulovesicular membrane. The distribution pattern of the intramembranous particles on the $\mathrm{P}$ face of the tubulovesicular membrane resembled that seen on the luminal plasma membrane (Fig. 4). Luminal surface microvilli appeared as numerous globules about $0.1 \mu \mathrm{m}$ in diameter when fractured transversally, or elongated rods when fractured longitudinally, and possessed numerous intramembranous particles on the $\mathrm{P}$ face of the plasma membrane (Fig. 5,6). Along the apical part of the lateral plasma membrane of the parietal cell, a tight junction was seen (Fig. 6). The distribution pattern of the intramembranous particles was clearly outlined by the tight junctional meshworks. Intramembranous particles were abundant on the luminal plasma membrane (Fig. 4), but relatively scarce on the basolateral plasma membrane (Fig. 6, 7).

A noteworthy finding was the presence of numerous branched strands on the fractured basolateral plasma membrane. These structures were equivalent to the basal folds demonstrated by thin-section electron microscopy. They appeared as branched furrows on the $\mathrm{P}$ face (Fig. 7) and branched wrinkles on the $\mathrm{E}$ face (Fig. 8) of the plasma membrane. These basal strands were not seen uniformly on the fractured plasma membrane, but basal-strand-free plasma membrane domains were usually seen (Fig. 9). There was an apparent increase in the number of parietal cells with welldeveloped and well-ramified basal strands in the refed rats (Fig. 10). 


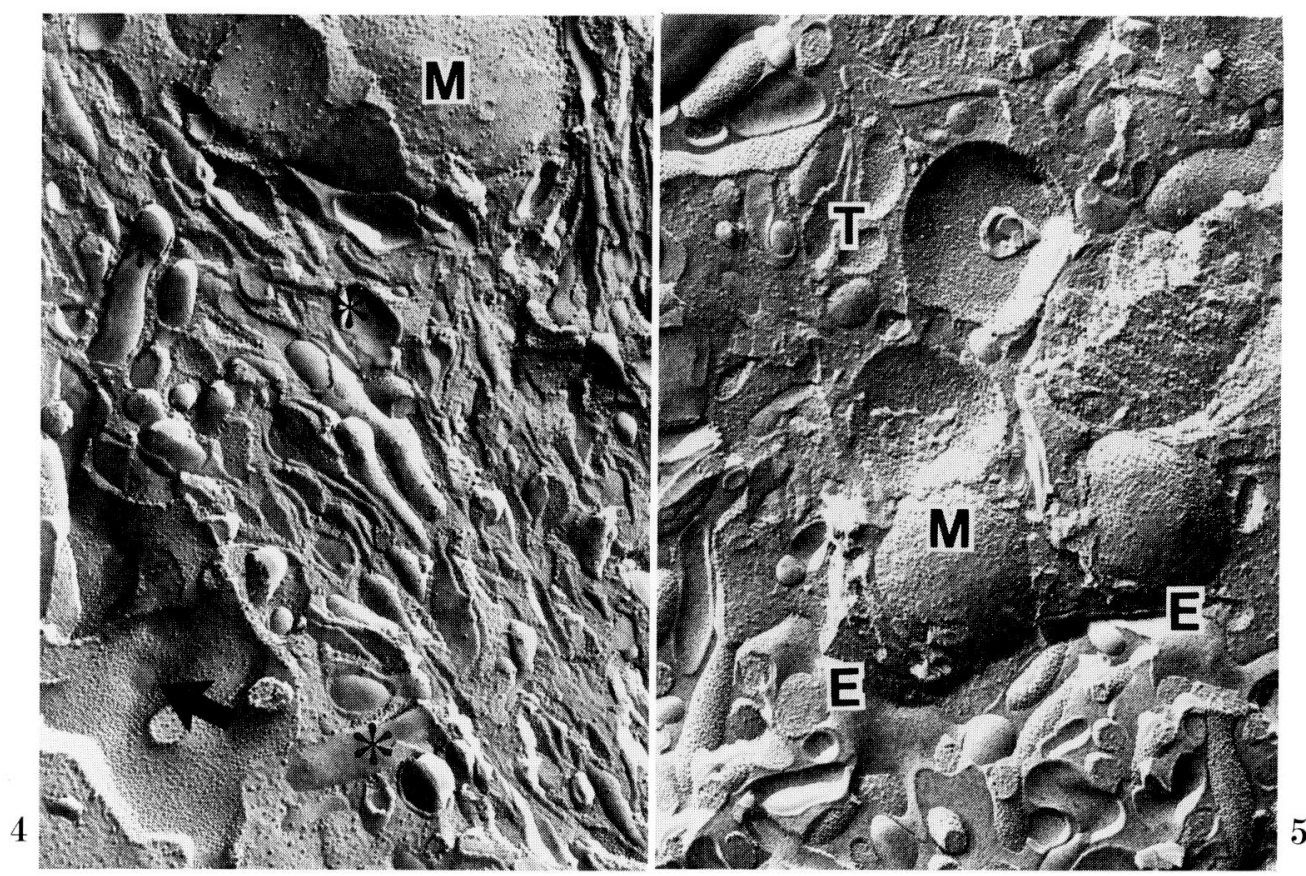

Fig. 4. An apical part of a parietal cell in a fasting rat. Abundant intramembranous particles can be seen on the P plasma membrane face of the luminal surface and tubulovesicular membrane. $E$ membrane face of tubulovesicles appears smooth (asterisks). Note the presence of intramembranous particle-free domains on the luminal surface (arrow). M mitochondria. $\times 44,000$

Fig. 5. An apical part of a parietal cell in a refed rat. The distribution pattern of intramembranous particles on the luminal plasma membrane $(E)$ closely resemble that seen on the tubulovesicular membrane $(T)$. Note the scanty tubulovesicles in the refed rat parietal cell. $M$ mitochondria. $\times 31,000$

\section{DISCUSSION}

Basal folds have been demonstrated in mammalian parietal cells (ITo and Schofield, 1974) and also in acid-secreting oxyntic cells of submammalian vertebrates (ForTE and Forte, 1970; Geuze, 1971; Helander and Durbin, 1977). Increment of the basal folds, accompanying the expansion of the luminal surface, has been pointed out in actively functioning parietal cells (Ito and Schofield, 1974; Schofield, Ito and Bolender, 1979). Our present study showed an en face view of the basolateral plasma membrane of the parietal cells. Active parietal cells in the refed rat had numerous basal folds. Reduction of the parietal cell volume during acid secretion has been shown in isolated rat parietal cells (BERGLINDH et al., 1976) and it was also confirmed in our present study. Considering these findings, it is reasonable to assume that the reduction of the cell volume brings about a surplus plasma membrane in the luminal and basolateral cell surfaces. A surplus plasma membrane in the luminal cell surface may be recovered by the dilatation of the canalicular lumen and the increased number of luminal microvilli.

Along the apicolateral cell surface, parietal cells are provided with well-developed tight junctions. They appear as numerous anastomosing belt-like structures between 


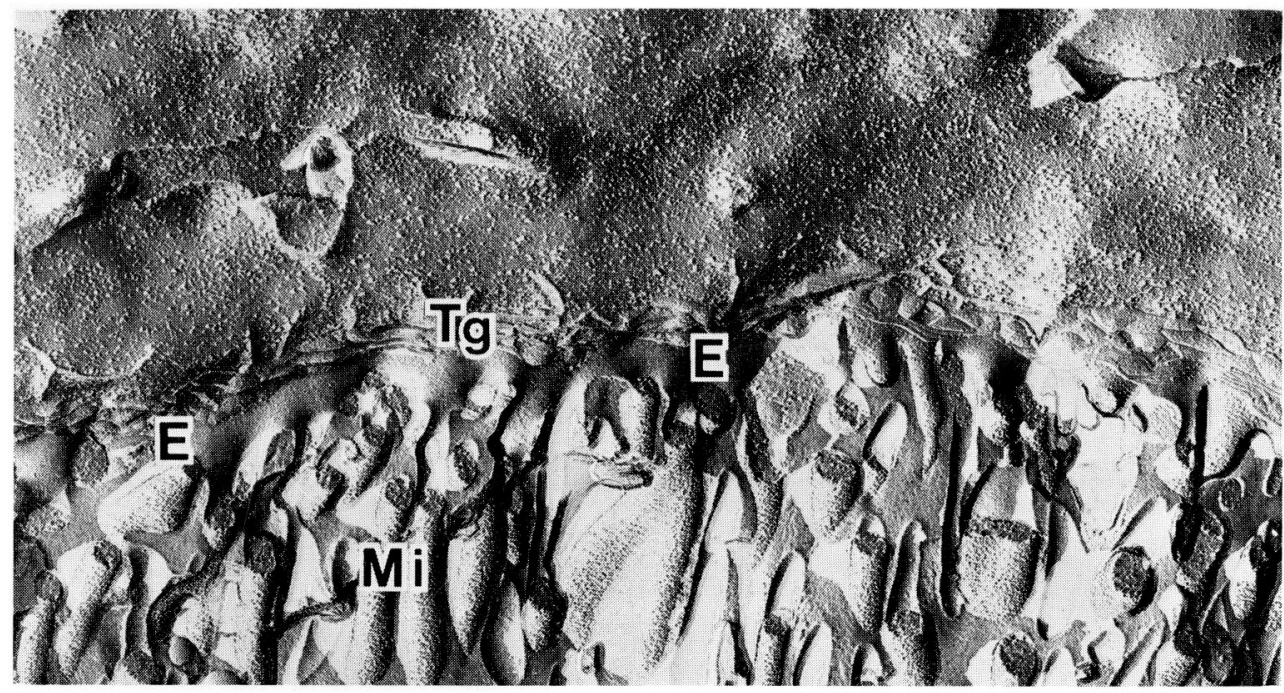

Fig. 6. A lateral part of a parietal cell in a refed rat. Note the marked difference in distribution pattern of intramembranous particles between lateral plasma membrane and luminal microvilli $(M i)$. Tight junctional meshworks $(T g)$ are seen between the luminal and lateral cell surface. E E plasma membrane face. $\times 31,000$

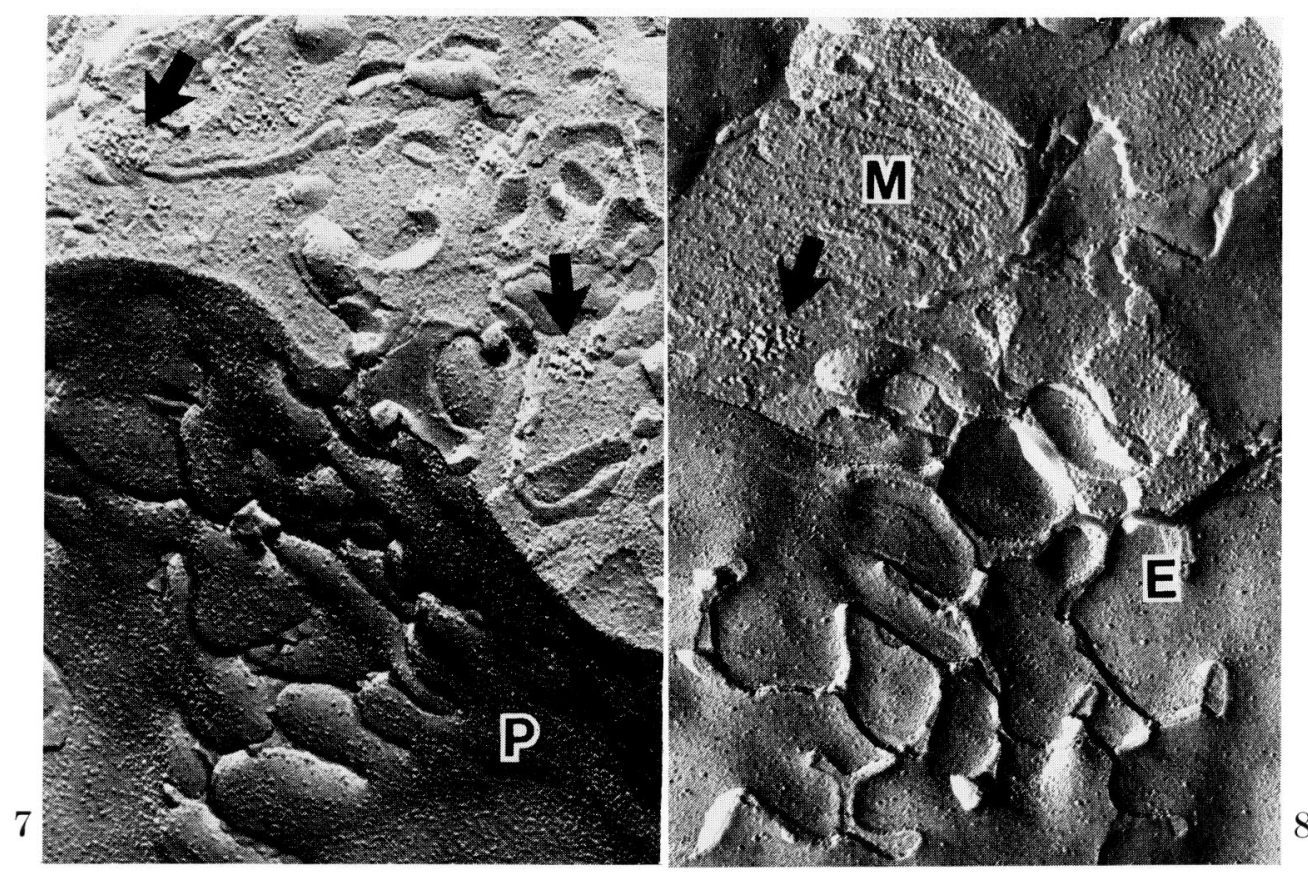

Fig. 7. $\quad$ P face of plasma membrane $(P)$ and cytoplasmic face of a basolateral part of a parietal cell in a fasting rat. Basal folds appear as branched furrows on the P plasma membrane face. Arrows indicate bundles of microfilaments. $\times 43,000$

Fig. 8. E face of a plasma membrane $(E)$ and cytoplasmic face of a basolateral part of a parietal cell in a fasting rat. Basal folds appear as branched wrinkles on the E plasma membrane face. The arrow indicates a bundle of microfilaments. $M$ mitochondria. $\times 43,000$ 

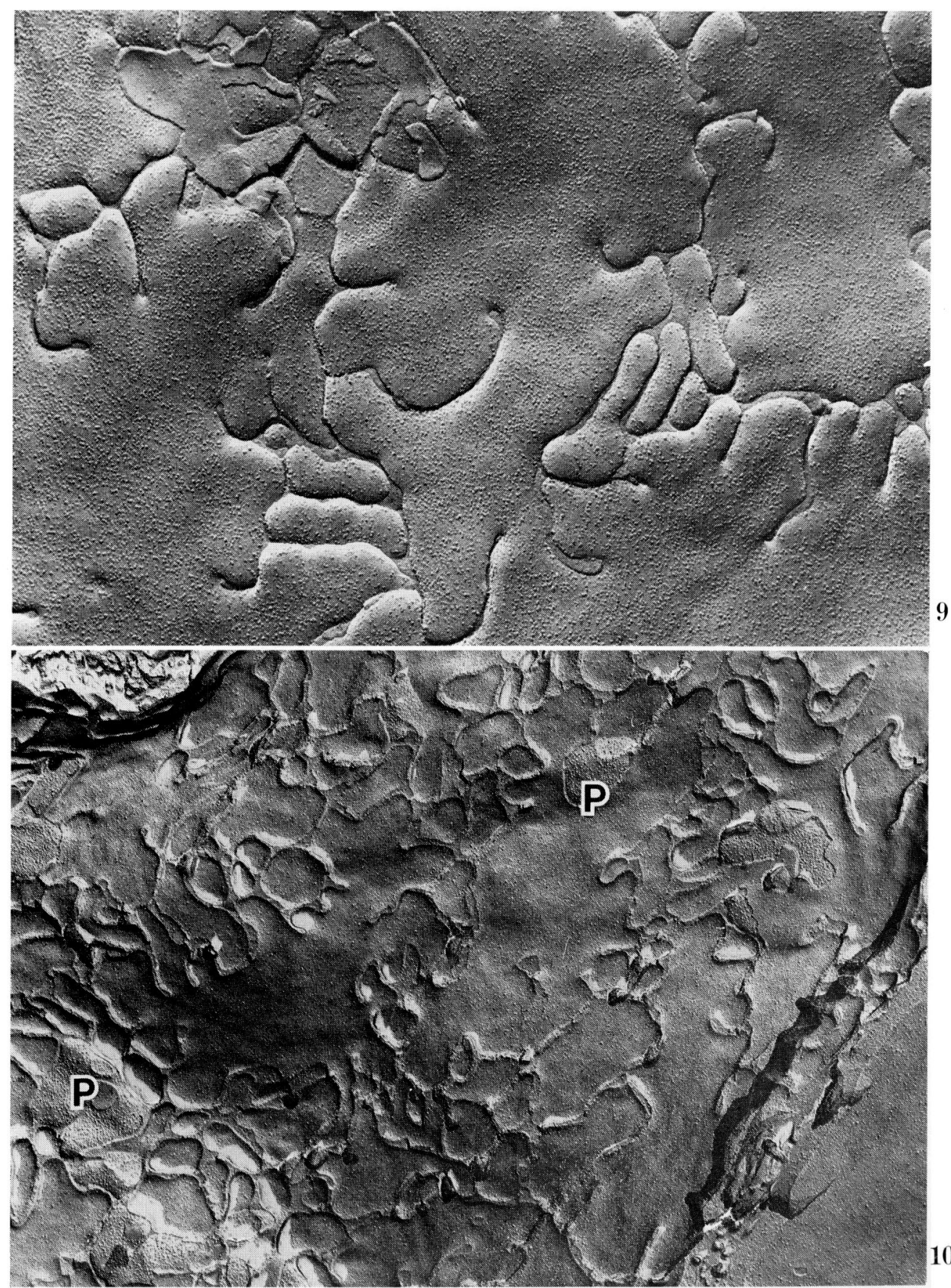

Fig. 9. Branched furrows of basal folds on the P plasma membrane face of the basolateral cell surface of a parietal cell in a fasting rat. $\times 36,000$

Fig. 10. Branched wrinkles of basal folds on the E plasma membrane face of the basolateral cell surface of a parietal cell in a refed rat. Note the well-ramified networks of the basal folds. $P$ P plasma membrane face. $\times 26,000$ 
adjacent cells and have been regarded as a permeable barrier. The distribution pattern of the intramembranous particle on the $\mathrm{P}$ plasma membrane face was markedly different between the luminal and basolateral plasma membranes. In previous freezefracture studies, the difference in the distribution pattern of intramembranous particles between the luminal and lateral plasma membranes has been indicated in pancreatic acinar cells (De Camilli, Peluchetti and Meldolesi, 1974), mammary gland cells (Ishimura, Kawamata and Fujit a, 1981) and Harderian gland cells (Winterhager and KÜHNEL, 1983). Moreover, it has been demonstrated that the tight junctional region can act as a barrier to the diffusion of membrane constituents (DRAGSTEN, BLUMENTHAL and HANDLER, 1981). Therefore, it may be ruled out that a surplus plasma membrane shifts across the tight junction from the basolateral to the luminal surface. It is likely that the volume reduction after acid secretion may cause a wrinkling of surplus plasma membrane in the basolateral cell surface. Basal folds may represent, at least to some extent, a reservoir for a surplus plasma membrane in the basal cell surface.

It has been widely accepted that basal folds are distributed in various epithelial cells, and thereby increase the cell surface area at the base of a cell. As a similar cell surface modification, microvilli increase the cell surface area at the apex of a cell. Cells provided with numerous microvilli have an advantage in secretion and absorption. It seems likely that a basal-fold-rich parietal cell, namely, the tubulovesicle-poor resting parietal cell in the refed rat, is also suited for absorbing raw materials required for acid production from the blood capillary via the underlying connective tissue. Moreover, it has been indicated that the active amphibian oxyntic cell secretes not only a gastric acid into the lumen but also secretes an equivalent amount of $\mathrm{HCO}_{3}$ - into the underlying connective tissue (O'BRIEN and BusCHELl, 1980). The basal-fold-rich cell surface seems well situated for $\mathrm{HCO}_{3}{ }^{-}$secretion into the underlying connective tissue. It seems likely that the number of the basal fold varies according to the secretory cycle of variety of epithelial cells.

\section{REFERENCES}

Berglindh, T., H. F. Helander and K. J. Öbrink : Effects of secretagogues on oxygen consumption, aminopyrine accumulation and morphology in isolated gastric glands. Acta physiol. scand. 97: 401-414 (1976).

Bordi, C. and A. Perrelet: Orthogonal arrays of particles in plasma membranes of the gastric parietal cell. Anat. Rec. 192: 297-304 (1978).

De Camilli, P., D. Peluchetti and J. Meldolesi : Structural difference between luminal and lateral plasmalemma in pancreatic acinar cells. Nature 248: 245-246 (1974).

Dragsten, P. R., R. Blumenthal and J. S. Handler: Membrane asymmetry in epithelia: is the tight junction a barrier to diffusion in the plasma membrane? Nature 294: 718-722 (1981).

Forte, T. M. and J. G. Forte: Histochemical staining and characterization of glycoproteins in acidsecreting cells of frog stomach. J. Cell Biol. 47: 437-452 (1970).

Geuze, J. J.: Light and electron microscope observations on the gastric mucosa of the frog (Rana esculenta). I. Normal structure. Z. Zellforsch. 117: 87-102 (1971).

Helander, H. F.: The cells of the gastric mucosa. Int. Rev. Cytol. 70: 217-289 (1981).

Helander, H. F. and R. P. Durbin: Secretory surface area and phosphatase activity of frog gastric mucosa. Amer. J. Physiol. 232: E48-E52 (1977).

Ishimura, K., S. Kawamata and H. Fujita : Freeze-fracture images of mammary glands of lactating mice. Anat. Embryol. 163: 173-183 (1981). 
Ito, S. and G. C. Schofield: Studies on the depletion and accumulation of microvilli and changes in the tubulovesicular compartment of mouse parietal cells in relation to gastric acid secretion. J. Cell Biol. 63: 364-382 (1974).

Kurosumi, K., S. Shibasaki, G. Uchida and Y. Tanaka : Electron microscope studies on the gastric mucosa of normal rats. Arch. histol. jap. 15: 587-624 (1958).

Leeson, T. S.: Canaliculi and tubulovesicles of rat parietal cells. Amer. J. Anat. 136: 541-547 (1973).

O'Brien, P. and M. Buschell: Role of acid-base status in the response of the isolated amphibian gastric mucosa to back diffusion of $\mathrm{H}^{+}$ions. Gastroenterology 79: 439-446 (1980).

Osawa, W. and T. Ogata: A scanning electron microscopic study on the fractured rat parietal cells in resting state and after stimulation with tetragastrin. Arch. histol. jap. 41: 141-155 (1978).

Sato, A., S. S. Spicer and R. E. Tashian: Ultrastructural localization of carbonic anhydrase in gastric parietal cells with the immunoglobulin-enzyme bridge method. Histochem. J. 12: 651-659 (1980).

Schofield, G. C., S. Ito and R. P. Bolender: Changes in membrane surface areas in mouse parietal cells in relation to high levels of acid secretion. J. Anat. 128: 669-692 (1979).

Shibasaki, S.: Experimental cytological and electron microscope studies on the rat gastric mucosa (In Japanese). Arch. histol. jap. 21: 251-288 (1961).

Winterhager, E. and W. Kühnel : Membrane specializations of the cells of the Harderian gland of the rabbit with particular reference to the mechanism of exocytosis. Cell Tiss. Res. 231: 623636 (1983).

\author{
平一男 \\ 干371 前橋市昭和町 3 丁目 \\ 群馬大学医学部 \\ 第一解剖学教室
}

Dr. Kazuo TAIRA

Department of Anatomy

Gunma University School of Medicine

Showa-machi, Maebashi

371 Japan 